\title{
VIBRATION ANALYSIS OF CROSS-PLY LAMINATED COMPOSITE DOUBLY CURVED SHALLOW SHELL PANELS WITH STIFFENERS
}

\author{
Trinh Anh Tuan ${ }^{1,}$, Tran Minh Tu${ }^{2}$, Tran Huu Quoc ${ }^{2}$, Nguyen Van Loi ${ }^{2}$ \\ ${ }^{1}$ HSE Training and Design Consultancy Company Limited, \\ 36B, 51 Lane, Doc Ngu Str., Ba Dinh Dist., Ha Noi \\ ${ }^{2}$ National University of Civil Engineering, 55 Giai Phong Road, Hai Ba Trung District, Ha Noi \\ "Email: tpnt2002@yahoo.com
}

Received: 30 October 2016; Accepted for publication: 14 March 2017

\begin{abstract}
In this paper, the analytical solution for the cross-ply laminated composite double curved shell panels with stiffeners is presented. The motion equations are derived by applying the Hamilton's principle, the smeared stiffeners technique, and using the first shear deformation theory (FSDT). The Navier's solution for the simply supported boundary condition both ends is presented. The accuracy of the results is compared with those in the existing literature and shows good achievement. The effects of the number of stiffeners, dimensions of stiffeners, and lamination scheme of cross-ply laminated composite shell panels on the natural fundamental frequencies are investigated.
\end{abstract}

Keywords: vibration analysis, cross-ply laminated composite, doubly curved shallow shell, stiffened shell, first shear deformation theory.

\section{INTRODUCTION}

Laminated composite shells are widely used in various engineering branches due to many advantages in comparing with conventional metallic materials such as higher strength-to-weight and stiffness-to-weight ratios, improved chemical and environmental resistance, durability and the ability to tailor properties. Shell structures reinforced by stringers (x-direction) and rings (ydirection) to achieve greater strength with the economy of the material. Hence, they have gained many applications in civil, mechanical, and aerospace engineering (e.g., commercial vehicles, aircraft fuselages, wings, road tankers, naval vessels, ship hulls, submarines, etc.).

Stiffened shells are frequently subjected to dynamic loadings in their service life, in order to understand in-service behaviors and resonance frequencies, the dynamic properties, such as natural frequencies need to be determined. In term of isotropic shells, Rhinehart and Wang [1] investigated the vibration of simply supported cylindrical shells stiffened by discrete longitudinal stiffeners using an energy method. Mustafa and Ali [2] determined dynamic characteristics of a simply supported ring stiffened, two stringer stiffened and an orthogonally 
stiffened cylindrical shell. These authors [3] also studied the free vibration characteristics of stiffened cylindrical shells and orthogonally stiffened cylindrically curved panels experimentally as well as numerically by using finite element method. Finite element method is also used to investigate vibration characteristics of stiffened shallow shell by Sinha and Mukhopadhyay [4], Nayak and Bandyopadhyay [5], etc.

Stiffened functionally graded (FG) shell structures are used mainly in the high-temperature environment and have been receiving considerably more attention in the recent years. Based on smeared technique, many authors developed the analytical solution for static and dynamic, linear and nonlinear response of stiffened FG shells. Studies of nonlinear dynamical analysis of eccentrically stiffened cylindrical and doubly curved shallow shell can be found in Bich et al. [6, 7]. Duc at al. [8,9] presented the nonlinear dynamic behavior and the nonlinear post-buckling of imperfect eccentrically stiffened P-FGM double curved thin shallow shell resting on the elastic foundation in the normal and thermal environments. Recently, Duc and Quan [10] analyzed the nonlinear vibration and dynamic response of imperfect functionally graded materials thick double-curved shallow shells resting on elastic foundations in thermal environments by using Reddy's third-order shear deformation shell theory. The buckling analysis of functionally graded stiffened cylindrical shells under uniformly axial compression load is investigated in work of Najafizadeh et al. [11]. Wattanasakulpong and Chaikittiratana [12] performed free vibration analysis of functionally graded stiffened doubly curved shallow shells under thermal environment. Note that the above-mentioned solutions are only analytical.

The investigation on the vibration of laminated composite stiffened shells is still meager. The work of Reddy [13] presented the exact solutions of moderately thick laminated shells, the results for the cross-ply laminated composite doubly curved shell panels were reported. Finite element free vibration analysis of laminated composite stiffened shell was carried out by Goswami and Mukhopadhyay [14]. Numerical investigation for stiffened composite cylindrical shells and doubly curved shells has been presented for both concentric and eccentric stiffeners. Prusty [15] presented finite element free vibration and buckling analysis of laminated hatstiffened shallow and deep shells using arbitrarily oriented stiffener formulation. Parametric study on the hat-stiffened panels for the free vibration and buckling analyses with closed and opened section stiffener were investigated. Finite element free vibration analysis of stiffened composite shells is also studied by Nayak and Bandyopadhyay [16], Li et al. [17], Rikards et al. [18], etc. The work of Bert et al. [19] used the five different thin shell theories and analytical approach determined the natural frequencies of laminated composite circular cylindrical shell stiffened by the ring and/or stringer stiffeners.

From above-mentioned studies on vibration characteristics of stiffened shell structures, it can be seen that the most of them focused on stiffened circular cylinder and used classical shell theory which does not take into account the effects of shear deformation and rotatory inertia. To the best of author's knowledge information regarding the analytical solution of free vibration behavior of composite stiffened cylindrical panel is missing in the literature except Bert's work [19].

The purpose of the present paper is to develop an analytical solution on the free vibration of cross-ply laminated composite stiffened doubly curved shallow shell panels. The present study used the first order shear deformation theory and smeared technique. Parametric studies are investigated and may be useful for the preliminary design of dynamically loaded, stiffened laminated composite shells. 


\section{THEORETICAL FORMULATION}

Consider a cross-ply laminated composite doubly curved shallow shell panel with stiffeners in coordinate $(\mathrm{x}, \mathrm{y}, \mathrm{z})$ as shown in Fig. 1; Symbols $\mathrm{a}, \mathrm{b}$ and $\mathrm{h}$ are lengths of the shell in the $\mathrm{x}-$ direction, $y$-direction, and thickness of the shell, respectively. $R_{1}$ and $R_{2}$ are principal radii of shell in the $\mathrm{x}$ - and $\mathrm{y}$-directions, respectively.

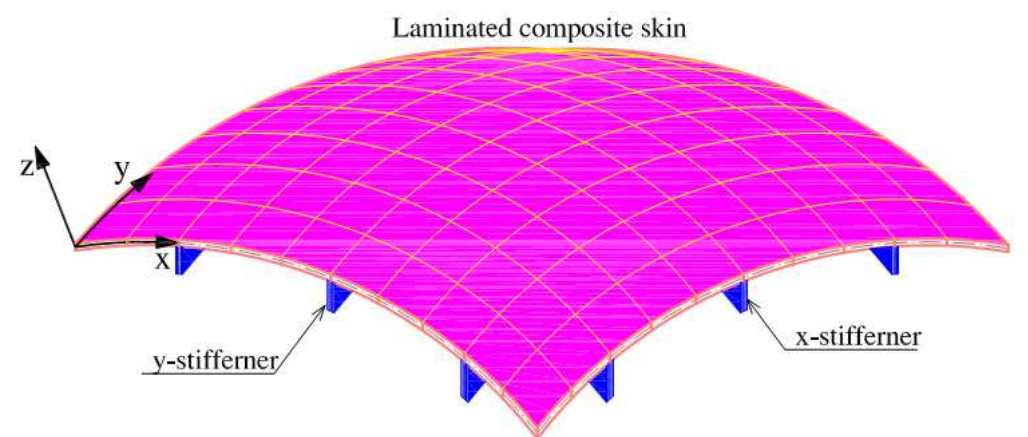

Figure 1. A cross-ply laminated composite doubly curved shallow shell panel with $\mathrm{x}$ - and y-stiffeners.

The displacement components of the FSDT of a point in the shell as follows [12, 20]:

$$
\begin{aligned}
& \mathrm{u}(\mathrm{x}, \mathrm{y}, \mathrm{z}, \mathrm{t})=\mathrm{u}_{0}(\mathrm{x}, \mathrm{y}, \mathrm{t})+\mathrm{z} \phi_{\mathrm{x}}(\mathrm{x}, \mathrm{y}, \mathrm{t}) \\
& \mathrm{v}(\mathrm{x}, \mathrm{y}, \mathrm{z}, \mathrm{t})=\mathrm{v}_{0}(\mathrm{x}, \mathrm{y}, \mathrm{t})+\mathrm{z} \phi_{\mathrm{y}}(\mathrm{x}, \mathrm{y}, \mathrm{t}) \\
& \mathrm{w}(\mathrm{x}, \mathrm{y}, \mathrm{z}, \mathrm{t})=\mathrm{w}_{0}(\mathrm{x}, \mathrm{y}, \mathrm{t})
\end{aligned}
$$

where $\mathrm{u}_{0}, \mathrm{v}_{0}, \mathrm{w}_{0}$ are the displacement components in the mid-surface corresponding to the $\mathrm{x}-, \mathrm{y}$ and z-directions. And $\phi_{\mathrm{x}}$ and $\phi_{\mathrm{y}}$ are slopes of transverse normal about the $\mathrm{x}$ - and y-axes.

The strain components of an arbitrary point in the shell are of the form:

$$
\left\{\begin{array}{c}
\varepsilon_{\mathrm{x}} \\
\varepsilon_{\mathrm{y}} \\
\gamma_{\mathrm{xy}}
\end{array}\right\}=\left\{\begin{array}{c}
\varepsilon_{\mathrm{x}}^{0} \\
\varepsilon_{\mathrm{y}}^{0} \\
\gamma_{\mathrm{xy}}^{0}
\end{array}\right\}+\mathrm{z}\left\{\begin{array}{c}
\kappa_{\mathrm{x}} \\
\kappa_{\mathrm{y}} \\
\kappa_{\mathrm{xy}}
\end{array}\right\} ; \quad\left\{\begin{array}{l}
\gamma_{\mathrm{yz}} \\
\gamma_{\mathrm{xz}}
\end{array}\right\}=\left\{\begin{array}{c}
\gamma_{\mathrm{yz}}^{0} \\
\gamma_{\mathrm{xz}}^{0}
\end{array}\right\}=\left\{\begin{array}{l}
\phi_{\mathrm{y}}+\frac{\partial \mathrm{w}_{0}}{\partial \mathrm{y}}-\frac{\mathrm{v}_{0}}{\mathrm{R}_{2}} \\
\phi_{\mathrm{x}}+\frac{\partial \mathrm{w}_{0}}{\partial \mathrm{x}}-\frac{\mathrm{u}_{0}}{\mathrm{R}_{1}}
\end{array}\right\}
$$

where

$$
\begin{aligned}
& \varepsilon_{\mathrm{x}}^{0}=\frac{\partial \mathrm{u}_{0}}{\partial \mathrm{x}}+\frac{\mathrm{w}_{0}}{\mathrm{R}_{1}} ; \varepsilon_{\mathrm{y}}^{0}=\frac{\partial \mathrm{v}_{0}}{\partial \mathrm{y}}+\frac{\mathrm{w}_{0}}{\mathrm{R}_{2}} ; \gamma_{\mathrm{xy}}^{0}=\frac{\partial \mathrm{u}_{0}}{\partial \mathrm{y}}+\frac{\partial \mathrm{v}_{0}}{\partial \mathrm{x}} \\
& \kappa_{\mathrm{x}}=\frac{\partial \phi_{\mathrm{x}}}{\partial \mathrm{x}} ; \kappa_{\mathrm{y}}=\frac{\partial \phi_{\mathrm{y}}}{\partial \mathrm{y}} ; \kappa_{\mathrm{xy}}=\frac{\partial \phi_{\mathrm{x}}}{\partial \mathrm{y}}+\frac{\partial \phi_{\mathrm{y}}}{\partial \mathrm{x}}
\end{aligned}
$$

The constitutive equation of $k$-layer of laminated composite shell can be written as [20]: 


$$
\left\{\begin{array}{c}
\sigma_{\mathrm{x}} \\
\sigma_{\mathrm{y}} \\
\sigma_{\mathrm{xy}} \\
\sigma_{\mathrm{yz}} \\
\sigma_{\mathrm{xz}}
\end{array}\right\}_{\mathrm{k}}=\left[\begin{array}{ccccc}
\overline{\mathrm{Q}}_{11} & \overline{\mathrm{Q}}_{12} & \overline{\mathrm{Q}}_{16} & 0 & 0 \\
\overline{\mathrm{Q}}_{12} & \overline{\mathrm{Q}}_{22} & \overline{\mathrm{Q}}_{26} & 0 & 0 \\
\overline{\mathrm{Q}}_{16} & \overline{\mathrm{Q}}_{26} & \overline{\mathrm{Q}}_{66} & 0 & 0 \\
0 & 0 & 0 & \overline{\mathrm{Q}}_{44} & \overline{\mathrm{Q}}_{45} \\
0 & 0 & 0 & \overline{\mathrm{Q}}_{45} & \overline{\mathrm{Q}}_{55}
\end{array}\right]_{\mathrm{k}}\left\{\begin{array}{c}
\varepsilon_{\mathrm{x}} \\
\varepsilon_{\mathrm{y}} \\
\gamma_{\mathrm{xy}} \\
\gamma_{\mathrm{yz}} \\
\gamma_{\mathrm{xz}}
\end{array}\right\}_{\mathrm{k}}
$$

where $\sigma_{\mathrm{x}}, \sigma_{\mathrm{y}}, \sigma_{\mathrm{xy}}, \sigma_{\mathrm{yz}}, \sigma_{\mathrm{xz}}$ and $\varepsilon_{\mathrm{x}}, \varepsilon_{\mathrm{y}}, \gamma_{\mathrm{xy}}, \gamma_{\mathrm{yz}}, \gamma_{\mathrm{xz}}$ are the stress and strain components in the global coordinate system - laminate coordinates $(\mathrm{x}, \mathrm{y}, \mathrm{z})$ of laminated composite shell; $\overline{\mathrm{Q}}_{\mathrm{ij}}$ 's are the transformed elastic constants with respect to the global coordinate system $(\mathrm{x}, \mathrm{y}, \mathrm{z})$, see more detail in [20].

For stringers, internal stringers used to reinforce for the shell panel, the material properties are isotropic. The geometry of the cross-ply laminated composite shallow shell panel with internal stiffeners in the $\mathrm{x}-\mathrm{z}$ plane illustrated in Fig. 2. Denote $\mathrm{E}_{\mathrm{x}}, \rho_{\mathrm{x}}, \mathrm{A}_{\mathrm{x}}, \mathrm{b}_{\mathrm{x}}, \mathrm{h}_{\mathrm{x}}, \mathrm{e}_{\mathrm{x}}, \mathrm{l}_{\mathrm{x}}$ and $\mathrm{E}_{\mathrm{y}}, \rho_{\mathrm{y}}, \mathrm{A}_{\mathrm{y}}, \mathrm{b}_{\mathrm{y}}, \mathrm{h}_{\mathrm{y}}, \mathrm{e}_{\mathrm{y}}, \mathrm{l}_{\mathrm{y}}$ as Young's modulus of stiffener material, mass density, cross-sectional area, the width of stringer, the height of stringer, the eccentricity of the stringer and the space between stringers in the $\mathrm{x}$ - and $\mathrm{y}$-directions, respectively.

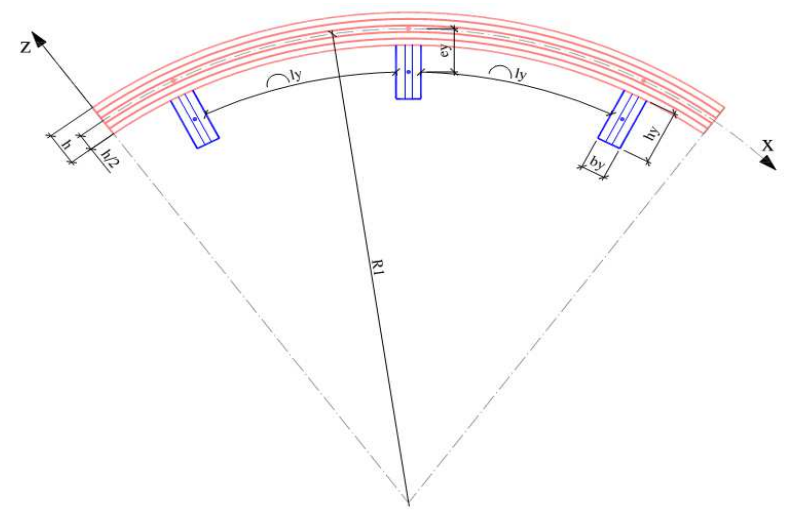

Figure 2. Geometry of cross-ply shallow shell panel with internal stiffeners in x-z plane.

Stiffeners are assumed to be in uniaxial state of stress. The displacement terms in the longitudinal are similar to those of the shell. Hence, the stress-strain relations of the stringers in the $\mathrm{x}$ - and $\mathrm{y}$-direction as:

$$
\sigma_{\mathrm{xx}}^{(\mathrm{x})}=\mathrm{E}_{\mathrm{x}}\left(\frac{\partial \mathrm{u}_{0}}{\partial \mathrm{x}}+\frac{\partial \mathrm{w}_{0}}{\mathrm{R}_{1}}\right)+\mathrm{E}_{\mathrm{x}} \mathrm{z} \frac{\partial \phi_{\mathrm{x}}}{\partial \mathrm{x}} ; \quad \sigma_{\mathrm{yy}}^{(\mathrm{y})}=\mathrm{E}_{\mathrm{y}}\left(\frac{\partial \mathrm{v}_{0}}{\partial \mathrm{y}}+\frac{\partial \mathrm{w}_{0}}{\mathrm{R}_{2}}\right)+\mathrm{E}_{\mathrm{y}} \mathrm{z} \frac{\partial \phi_{\mathrm{y}}}{\partial \mathrm{y}}
$$

The effects of the stiffness of the stringers are assumed to be smeared over the shell and to ignore twist effect. The smeared stiffeners technique be used for the global behavior of shell panels with the assumption that the stiffeners space uniformly. The moment and force resultants of the stiffened shell are as follows [6, 12]: 


$$
\begin{aligned}
& \left\{\begin{array}{l}
\mathrm{N}_{\mathrm{xx}} \\
\mathrm{N}_{\mathrm{yy}} \\
\mathrm{N}_{\mathrm{xy}}
\end{array}\right\}=\int_{-\mathrm{h} / 2}^{\mathrm{h} / 2}\left\{\begin{array}{l}
\sigma_{\mathrm{xx}} \\
\sigma_{\mathrm{yy}} \\
\tau_{\mathrm{xy}}
\end{array}\right\} \mathrm{dz}+\left\{\begin{array}{c}
\frac{1}{1_{\mathrm{x}}} \int_{\mathrm{A}_{\mathrm{x}}} \sigma_{\mathrm{xx}}^{(\mathrm{x})} \mathrm{d} \mathrm{A}_{\mathrm{x}} \\
\frac{1}{1_{\mathrm{y}}} \int_{\mathrm{A}_{\mathrm{y}}} \sigma_{\mathrm{yy}}^{(\mathrm{y})} \mathrm{d} \mathrm{A}_{\mathrm{y}} \\
0
\end{array}\right\} ;\left\{\begin{array}{l}
\mathrm{M}_{\mathrm{xx}} \\
\mathrm{M}_{\mathrm{yy}} \\
\mathrm{M}_{\mathrm{xy}}
\end{array}\right\}=\int_{-\mathrm{h} / 2}^{\mathrm{h} / 2}\left\{\begin{array}{l}
\mathrm{z} \sigma_{\mathrm{xx}} \\
\mathrm{z} \sigma_{\mathrm{yy}}
\end{array}\right\} \mathrm{dz}+\left\{\begin{array}{c}
\frac{1}{1_{\mathrm{x}}} \int_{\mathrm{A}_{\mathrm{x}}} \mathrm{z} \sigma_{\mathrm{xx}}^{(\mathrm{x})} \mathrm{d} \mathrm{A}_{\mathrm{x}} \\
\frac{1}{1_{\mathrm{y}}} \int_{\mathrm{A}_{\mathrm{y}}} \mathrm{z} \sigma_{\mathrm{yy}}^{(\mathrm{y})} \mathrm{dA} \mathrm{A}_{\mathrm{y}} \\
0
\end{array}\right\} \\
& \left\{\begin{array}{c}
\mathrm{N}_{\mathrm{x}} \\
\mathrm{N}_{\mathrm{y}} \\
\mathrm{N}_{\mathrm{xy}} \\
\mathrm{M}_{\mathrm{x}} \\
\mathrm{M}_{\mathrm{y}} \\
\mathrm{M}_{\mathrm{xy}}
\end{array}\right\}=\left[\begin{array}{cccccc}
\mathrm{A}_{11}^{\prime} & \mathrm{A}_{12}^{\prime} & 0 & \mathrm{~B}_{11}^{\prime} & \mathrm{B}_{12}^{\prime} & 0 \\
\mathrm{~A}_{12}^{\prime} & \mathrm{A}_{22}^{\prime} & 0 & \mathrm{~B}_{12}^{\prime} & \mathrm{B}_{22}^{\prime} & 0 \\
0 & 0 & \mathrm{~A}_{66}^{\prime} & 0 & 0 & \mathrm{~B}_{66}^{\prime} \\
\mathrm{B}_{11}^{\prime} & \mathrm{B}_{12}^{\prime} & 0 & \mathrm{D}_{11}^{\prime} & \mathrm{D}_{12}^{\prime} & 0 \\
\mathrm{~B}_{12}^{\prime} & \mathrm{B}_{22}^{\prime} & 0 & \mathrm{D}_{12}^{\prime} & \mathrm{D}_{22}^{\prime} & 0 \\
0 & 0 & \mathrm{~B}_{66}^{\prime} & 0 & 0 & \mathrm{D}_{66}^{\prime}
\end{array}\right]\left\{\begin{array}{c}
\varepsilon_{\mathrm{x}}^{0} \\
\varepsilon_{\mathrm{y}}^{0} \\
\gamma_{\mathrm{xy}}^{0} \\
\kappa_{\mathrm{x}} \\
\kappa_{\mathrm{y}} \\
\kappa_{\mathrm{xy}}
\end{array}\right\} ;\left\{\begin{array}{l}
\mathrm{Q}_{\mathrm{y}} \\
\mathrm{Q}_{\mathrm{x}}
\end{array}\right\}=\mathrm{k}_{\mathrm{s}}\left[\begin{array}{cc}
\mathrm{A}_{44} & 0 \\
0 & \mathrm{~A}_{55}
\end{array}\right]\left\{\begin{array}{c}
\gamma_{\mathrm{yz}}^{0} \\
\gamma_{\mathrm{xz}}^{0}
\end{array}\right\}
\end{aligned}
$$

where

$$
\begin{aligned}
& A_{11}^{\prime}=A_{11}+\frac{E_{x} A_{x}}{l_{x}} ; A_{12}^{\prime}=A_{12} ; A_{22}^{\prime}=A_{22}+\frac{E_{y} A_{y}}{l_{y}} ; A_{66}^{\prime}=A_{66} \\
& B_{11}^{\prime}=B_{11}+\frac{E_{x} A_{x} e_{x}}{l_{x}} ; B_{12}^{\prime}=B_{12} ; B_{22}^{\prime}=B_{22}+\frac{E_{y} A_{y} e_{y}}{l_{y}} ; B_{66}^{\prime}=B_{66} \\
& D_{11}^{\prime}=D_{11}+\frac{E_{x} I_{x}}{l_{x}} ; D_{12}^{\prime}=D_{12} ; D_{22}^{\prime}=D_{22}+\frac{E_{y} I_{y}}{l_{y}} ; D_{66}^{\prime}=D_{66}
\end{aligned}
$$

With

$$
\begin{array}{r}
I_{x}=\frac{b_{x} h_{x}^{3}}{12}+e_{x}^{2} A_{x}, I_{y}=\frac{b_{y} h_{y}^{3}}{12}+e_{y}^{2} A_{y} ; e_{x}=\frac{h_{x}+h}{2} ; e_{y}=\frac{h_{y}+h}{2} \\
\begin{cases}\left(A_{i j}, B_{i j}, D_{i j}\right)=\int_{-h / 2}^{h / 2} Q_{i j}\left(1, z, z^{2}\right) d z ; & (i j)=11,12,21,22,66 \\
A_{i j}=\int_{-h / 2}^{h / 2} Q_{i j} d z ; & (i j)=44,55\end{cases}
\end{array}
$$

The parameter $\mathrm{k}_{\mathrm{s}}$ is the shear correction factor $\left(\mathrm{k}_{\mathrm{s}}=5 / 6\right)$.

Applying Hamilton's principle, the governing equations of shell using the FSDT is given as $[12,20]$ :

$$
\begin{aligned}
& \frac{\partial N_{x x}}{\partial x}+\frac{\partial N_{x y}}{\partial y}+\frac{Q_{x z}}{R_{1}}=I_{0} \ddot{u}_{0}+I_{1} \ddot{\phi}_{x} ; \frac{\partial N_{x y}}{\partial x}+\frac{\partial N_{y y}}{\partial y}+\frac{Q_{y z}}{R_{2}}=I_{0} \ddot{v}_{0}+I_{1} \ddot{\phi}_{y} \\
& \frac{\partial Q_{x z}}{\partial x}+\frac{\partial Q_{y z}}{\partial y}-\frac{N_{x x}}{R_{1}}-\frac{N_{y y}}{R_{2}}=I_{0} \ddot{\mathrm{w}}_{0} \\
& \frac{\partial M_{x x}}{\partial x}+\frac{\partial M_{x y}}{\partial y}-Q_{x z}=I_{1} \ddot{u}_{0}+I_{2} \ddot{\phi}_{x} ; \frac{\partial M_{x y}}{\partial x}+\frac{\partial M_{y y}}{\partial y}-Q_{y z}=I_{1} \ddot{v}_{0}+I_{2} \ddot{\phi}_{y}
\end{aligned}
$$

where 


$$
\left\{\mathrm{I}_{\mathrm{i}}=\int_{-\mathrm{h} / 2}^{\mathrm{h} / 2} \rho_{\mathrm{eq}} \mathrm{z}^{\mathrm{i}} \mathrm{dz} \quad \mathrm{i}=(0,1,2) ; \quad \rho_{\mathrm{eq}}=\rho+\left(\frac{\mathrm{A}_{\mathrm{x}}}{1_{\mathrm{x}} \mathrm{h}}\right) \rho_{\mathrm{x}}+\left(\frac{\mathrm{A}_{\mathrm{y}}}{l_{\mathrm{y}} \mathrm{h}}\right) \rho_{\mathrm{y}}\right.
$$

with $\rho$ is the mass density of laminate composite shell.

The above moment and force resultants are expressed by displacement terms of Eq. (1). And then substituting the obtained results in Eq. (10), we get the equilibrium equations with respect to displacement terms of Eq. (10).

\section{SOLUTION PROCEDURES}

In this study, the free vibration of the simply supported cross-ply laminated composite doubly curved shallow shell panels is developed by using Navier's solution. The displacement expressions are assumed as:

$$
\left\{\begin{array}{l}
\mathrm{u}_{0}(\mathrm{x}, \mathrm{y}, \mathrm{t}) \\
\mathrm{v}_{0}(\mathrm{x}, \mathrm{y}, \mathrm{t}) \\
\mathrm{w}_{0}(\mathrm{x}, \mathrm{y}, \mathrm{t}) \\
\phi_{\mathrm{x}}(\mathrm{x}, \mathrm{y}, \mathrm{t}) \\
\phi_{\mathrm{y}}(\mathrm{x}, \mathrm{y}, \mathrm{t})
\end{array}\right\}=\sum_{\mathrm{m}=1}^{\infty} \sum_{\mathrm{n}=1}^{\infty}\left\{\begin{array}{l}
\mathrm{u}_{\mathrm{mn}} \mathrm{e}^{\mathrm{i} \omega \mathrm{t}} \cos (\alpha \mathrm{x}) \sin (\beta \mathrm{y}) \\
\mathrm{v}_{\mathrm{mn}} \mathrm{e}^{\mathrm{i} \omega \mathrm{t}} \sin (\alpha \mathrm{x}) \cos (\beta \mathrm{y}) \\
\mathrm{w}_{\mathrm{mn}} \mathrm{e}^{\mathrm{i} \omega \mathrm{t}} \sin (\alpha \mathrm{x}) \sin (\beta \mathrm{y}) \\
\phi_{\mathrm{x} m \mathrm{n}} \mathrm{e}^{\mathrm{i} \omega \mathrm{t}} \cos (\alpha \mathrm{x}) \sin (\beta \mathrm{y}) \\
\phi_{\mathrm{ymn}} \mathrm{e}^{\mathrm{i} \omega \mathrm{t}} \sin (\alpha \mathrm{x}) \cos (\beta \mathrm{y})
\end{array}\right\}
$$

where $\mathrm{u}_{\mathrm{mn}}, \mathrm{v}_{\mathrm{mn}}, \mathrm{w}_{\mathrm{mn}}, \phi_{\mathrm{xmn}}, \phi_{\mathrm{ymn}}$ are the arbitrary coefficients; $\mathrm{i}$ is the imaginary unit, $\mathrm{i}^{2}=-1$; $\omega$ is natural frequency; $\alpha=\mathrm{m} \pi / \mathrm{a} ; \beta=\mathrm{n} \pi / \mathrm{b}$;

Substituting Eq. (12) into the equilibrium equation system with respect to displacement terms of Eq. (10), it obtained as follows:

$$
\left([\mathrm{K}]_{5 \times 5}-\omega^{2}[\mathrm{M}]_{5 \times 5}\right)\{\Delta\}_{5 \times 1}=\{0\}_{5 \times 1}
$$

where $\{\Delta\}_{5 \times 1}=\left\{\begin{array}{lllll}\mathrm{u}_{\mathrm{mn}} & \mathrm{v}_{\mathrm{mn}} & \mathrm{w}_{\mathrm{mn}} \phi_{\mathrm{xmn}} \phi_{\mathrm{ymn}}\end{array}\right\}^{\mathrm{T}}$, and coefficients $\mathrm{K}_{\mathrm{ij}}, \mathrm{M}_{\mathrm{ij}}$ are determined by using Symbolic Toolbox in MATLAB software. Solving Eq. (14) to get the natural frequency $\omega_{\mathrm{mn}}$.

\section{RESULTS AND DISCUSSIONS}

\subsection{Validation}

In this section, the two examples for the verification of present study are presented. It noted that the doubly curved shell panel can be changed to the various structural types by setting quantities as follows:

$$
\begin{aligned}
& \frac{\mathrm{a}}{\mathrm{R}_{1}}=\frac{\mathrm{b}}{\mathrm{R}_{2}}=0 \text { for a flat plate; } \\
& \frac{\mathrm{a}}{\mathrm{R}_{1}}=0 \text { for a cylindrical shell panel; } \frac{\mathrm{a}}{\mathrm{R}_{1}}=\frac{\mathrm{b}}{\mathrm{R}_{2}} \text { for a spherical shell panel }
\end{aligned}
$$

The first example, to verify the free vibration of the cross-ply laminated composite spherical shell panels without stiffeners. The comparison between the results of the present study 
with those of Reddy [13] using the FSDT (an extension of the Sanders shell theory). The results of the non-dimensional fundamental frequencies $\Omega_{\mathrm{i}}=\omega_{\mathrm{i}} \mathrm{a}^{2} \sqrt{\rho / \mathrm{E}_{2} / \mathrm{h}^{2}}$ are shown in Table 1 . The dimensions of the shell panel used are $\mathrm{a} / \mathrm{b}=1 ; \mathrm{a} / \mathrm{h}=100 ; \mathrm{R}_{1}=\mathrm{R}_{2}$; the lamination scheme $\left[0^{\circ} / 90^{\circ} / 0^{\circ}\right]$, and the material properties of the shell are $\mathrm{E}_{1}=25 \mathrm{E}_{2} ; \mathrm{G}_{12}=0.5 \mathrm{E}_{2}$; $\mathrm{G}_{23}=0.2 \mathrm{E}_{2} ; \mathrm{G}_{13}=\mathrm{G}_{12} ; v_{12}=0.25$. From this Table 1, it can be observed that the present results are identical with those of Reddy [13].

Table 1. Non-dimensional fundamental frequencies of the spherical shell panels.

\begin{tabular}{ccccccc}
\hline & \multicolumn{3}{c}{$0^{0} / 90^{0}$} & & $0^{0} / 90^{0} / 0^{0}$ \\
$\mathrm{~h} / \mathrm{R}_{1}$ & Reddy $[13]$ & Present & error & Reddy $[13]$ & Present & error \\
\hline 300 & 46.002 & $\mathbf{4 6 . 0 0 2}$ & $0.00 \%$ & 47.265 & $\mathbf{4 7 . 2 6 5}$ & $0.00 \%$ \\
400 & 35.228 & $\mathbf{3 5 . 2 2 8}$ & $0.00 \%$ & 36.971 & $\mathbf{3 6 . 9 7 1}$ & $0.00 \%$ \\
500 & 28.825 & $\mathbf{2 8 . 8 2 5}$ & $0.00 \%$ & 30.993 & $\mathbf{3 0 . 9 9 3}$ & $0.00 \%$ \\
1000 & 16.706 & $\mathbf{1 6 . 7 0 6}$ & $0.00 \%$ & 20.347 & $\mathbf{2 0 . 3 4 7}$ & $0.00 \%$ \\
Plate & 9.687 & $\mathbf{9 . 6 8 7}$ & $0.00 \%$ & 15.183 & $\mathbf{1 5 . 1 8 3}$ & $0.00 \%$ \\
\hline
\end{tabular}

The second example, to verify the natural fundamental frequency of the cross-ply laminated composite cylindrical shell panels with and without stiffeners. The comparison between the results of the present study with those also was calculated by the code ANSYS software employing the shell model. The composite stiffened shell was calculated by the shell model, both shell and stiffeners were also modeled and assembled by using the shell elements Shell281. In this case, the mesh was $12 \times 12$ for shell surface and was $12 \times 1$ for stiffeners surface. The results are presented in Table 2 .

The dimensions of cylindrical shell panel are $a=b=1 ; b / h=50 ; R_{2} / b=2 ; a / R_{1}=0$; lamination scheme $\left[0^{0} / 90^{\circ} / 0^{\circ} / 90^{\circ}\right]$; and the material properties of the shell are $\mathrm{E}_{1}=132.5 \mathrm{Gpa} ; \mathrm{E}_{2}=10.8 \mathrm{Gpa} ; \mathrm{G}_{12}=5.7 \mathrm{Gpa} ; \mathrm{G}_{13}=\mathrm{G}_{12} ; \mathrm{G}_{23}=3.4 \mathrm{Gpa} ; v_{12}=0.24$; $\rho=1600 \mathrm{~kg} / \mathrm{m}^{3}$.

For internal stiffeners used are $\mathrm{b}_{\mathrm{x}(\mathrm{y})}=\mathrm{h}_{\mathrm{x}(\mathrm{y})}=\mathrm{h} ; \mathrm{E}_{\mathrm{x}(\mathrm{y})}=3 \mathrm{E}_{2} ; \rho=1600 \mathrm{~kg} / \mathrm{m}^{3}$ (isotropic).

Table 2. Comparison of natural fundamental frequency of $\left[0^{0} / 90^{\circ} / 0^{0} / 90^{\circ}\right]$ cylindrical shell panels with and without stiffeners $(\mathrm{b} / \mathrm{a}=1)$.

\begin{tabular}{|c|c|c|c|c|c|c|}
\hline \multirow[b]{2}{*}{$\mathrm{b} / \mathrm{h}$} & \multirow[b]{2}{*}{$\mathrm{R}_{2} / \mathrm{b}$} & & \multirow[b]{2}{*}{ Unstiffened } & \multicolumn{3}{|c|}{ Stiffened (internal stringers) } \\
\hline & & & & $\begin{array}{l}\text { direction- } \mathrm{x} \\
\text { (1 stringer) }\end{array}$ & $\begin{array}{l}\text { direction-y } \\
\text { (1 ring) }\end{array}$ & $\begin{array}{c}\text { direction-x \& y } \\
\text { (1 stringer x } 1 \text { ring) }\end{array}$ \\
\hline \multirow{4}{*}{50} & \multirow{2}{*}{1} & ANSYS & 262.700 & 257.770 & 267.590 & 263.510 \\
\hline & & Present & 264.949 & 262.635 & 275.294 & 272.916 \\
\hline & \multirow{2}{*}{2} & ANSYS & 164.700 & 161.940 & 164.790 & 165.820 \\
\hline & & Present & 162.559 & 161.658 & 162.028 & 161.152 \\
\hline
\end{tabular}


As shown in Table 2, it can be seen that the maximum discrepancy is $3.57 \%$ for the crossply cylindrical shell panel with orthogonal stiffeners in the x-direction and y-direction $\left(b / h=50 ; R_{2} / b=1\right)$. From the above verification, it can be concluded that the results of present study are reliable.

In the following investigations, the dimensions and material properties of the shell panels used are: $\mathrm{a}=\mathrm{b}=1 \mathrm{~m} ; \mathrm{b} / \mathrm{h}=50 ; \mathrm{a} / \mathrm{R}_{1}=\mathrm{b} / \mathrm{R}_{2}=0.5$ (spherical shell); $\mathrm{a} / \mathrm{R}_{1}=0 ; \mathrm{b} / \mathrm{R}_{2}=0.5$ (cylindrical shell); $\quad \mathrm{E}_{1}=132.5 \mathrm{Gpa} ; \quad \mathrm{E}_{2}=10.8 \mathrm{Gpa} ; \quad \mathrm{G}_{12}=5.7 \mathrm{Gpa} ; \quad \mathrm{G}_{13}=\mathrm{G}_{12}$; $\mathrm{G}_{23}=3.4 \mathrm{Gpa} ; v_{12}=0.24 ; \rho=1600 \mathrm{~kg} / \mathrm{m}^{3}$. The material properties of internal stiffeners (only considered internal stiffeners) are $\mathrm{E}=3 \mathrm{E}_{2} ; \rho=1600 \mathrm{~kg} / \mathrm{m}^{3} ; v=0.24$. It is also noted that the stiffeners in the $\mathrm{x}$-direction can be called as stringers, and the stiffeners in the $\mathrm{y}$-direction can be called as rings for cylindrical shells.

\subsection{Effects of number of the stiffeners on the natural fundamental frequency}

In this investigation, the cross-ply laminated composite doubly curved shallow shell panels with lamination scheme $\left[0^{\circ} / 90^{\circ} / 0^{\circ} / 90^{\circ}\right]$ are carried out. Numbers of stiffeners in the $\mathrm{x}$ direction (stringers), in the y-direction (rings), and orthogonal stiffeners $\left(\mathrm{n}_{\mathrm{x}}=\mathrm{n}_{\mathrm{y}}\right)$ are $\mathrm{n}_{\mathrm{x}}, \mathrm{n}_{\mathrm{y}}=(0 ; 1 \div 18)$. The dimensions of the stiffeners are $\mathrm{b}_{\mathrm{x}}=\mathrm{h}_{\mathrm{x}}=\mathrm{h}$ and $\mathrm{b}_{\mathrm{y}}=\mathrm{h}_{\mathrm{y}}=\mathrm{h}$ (thickness of shell). The effects of the number of stiffeners on the natural fundamental frequency of the crossply spherical shell and cylindrical shell panels are shown in Fig. 3.
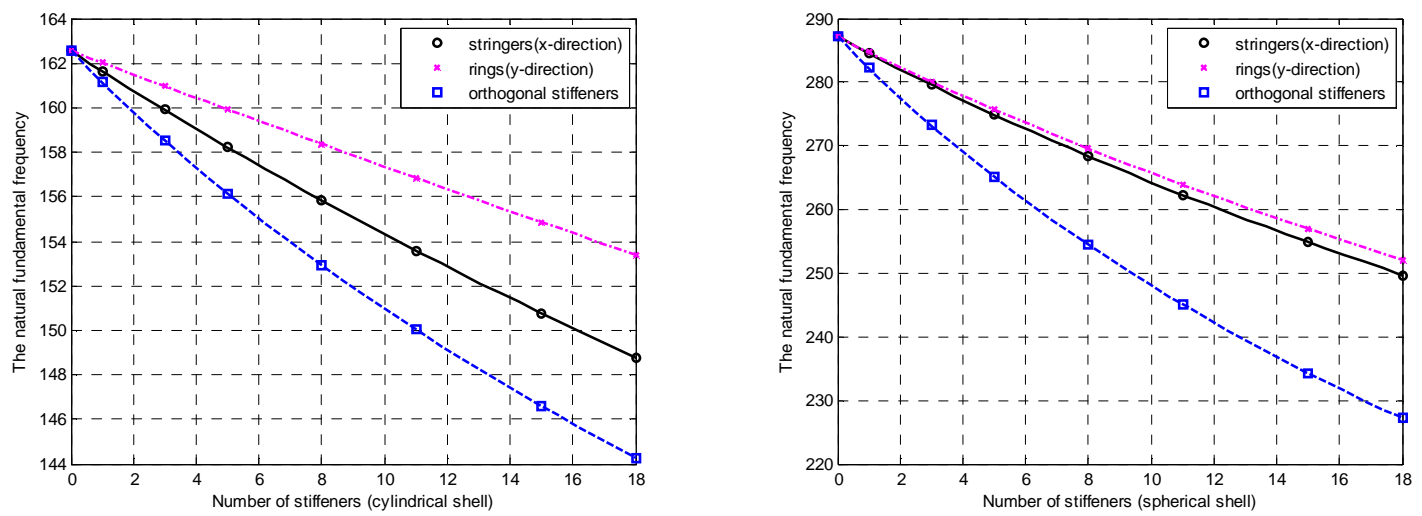

Figure 3. The effects of number of stiffeners on the natural fundamental frequency of cross-ply spherical shell and cylindrical shell panels.

Figure 3 shows that the natural fundamental frequencies of shell panel decrease when the number of stiffeners increases. This phenomenon is due to the increase of the mass is faster than the increase of the stiffness of shell panel. Besides, the natural fundamental frequencies of shell panels with rings are higher than those with stringers and orthogonal stiffeners. It shows that rings reinforce for shell panels are better than the others (more effective).

\subsection{Effects of the dimension of stiffeners on the natural fundamental frequency}


To investigate the effects of the dimension of the stiffeners on the natural fundamental frequency of shell panel, we use a parameter are called as dimension ratio of the stiffener $\left(h_{s} / b_{s}\right)$. The effects of dimension ratio of stiffener $\left(h_{s} / b_{s}\right)$ on the natural fundamental frequencies of the cross-ply spherical shell and cylindrical shell panels are plotted in Fig. 4. The cross-ply shell panels with lamination scheme $\left[0^{\circ} / 90^{\circ} / 0^{\circ} / 90^{\circ}\right]$, the number of the stiffeners in the $\mathrm{x}$-direction (stringers), the number of stiffeners in the y-direction (rings), and orthogonal stiffeners $\left(n_{x}=n_{y}\right)$ are nine stiffeners. The dimension of the stiffeners used are $b_{x}=b_{y}=h$ and $\mathrm{h}_{\mathrm{x}}=\mathrm{h}_{\mathrm{y}}=(0.5 \div 5) \mathrm{h} ; \mathrm{h}$ is the thickness of the shell.

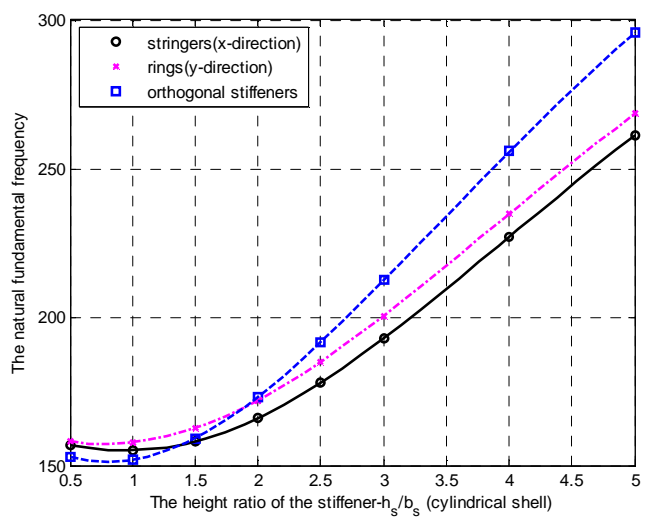

a)

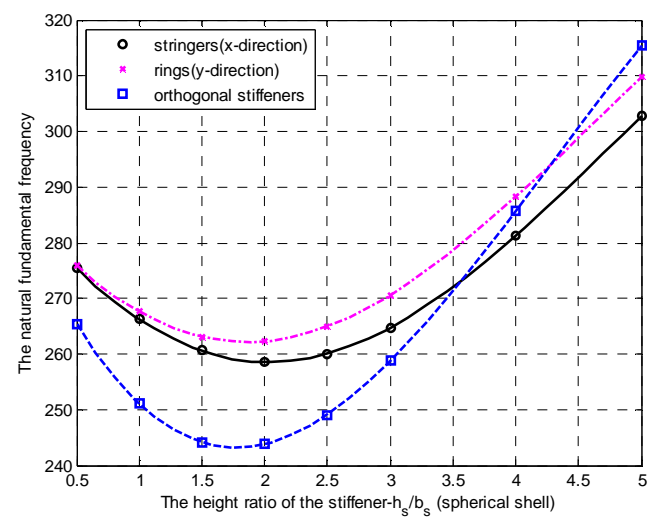

b)

Figure 4. The effects of dimension ratio of stiffener on the natural fundamental frequency of the cross-ply spherical shell and cylindrical shell panels.

It can be observed in Fig. 4, at the beginning, the natural fundamental frequencies of shell panel with rings are the largest at all then ones with orthogonal stiffeners increase rapidly to become ones are the largest. Let see Fig. 4a, for cylindrical shell panels, when the height of the stiffener is larger than twice the width of the stiffener $\left(b_{x}=b_{y}=h\right)$, the natural fundamental frequencies of the shell panel with orthogonal stiffeners is larger than those of with rings and stringers. However, for spherical shell panels, when the height of stiffener is larger than four times the width of the stiffener, the natural fundamental frequencies of the shell panel with orthogonal stiffeners is larger than those of the others.

\subsection{Effects of the lamination scheme of cross-ply laminated composite shell on the natural fundamental frequency}

To consider the effects of the lamination scheme of cross-ply laminate composite shell on the natural fundamental frequencies of the spherical shell and cylindrical shell panels with the stiffeners, the shell panels with nine stiffeners $\left(\mathrm{n}_{\mathrm{x}}=\mathrm{n}_{\mathrm{y}}=9\right)$ and lamination scheme $\left[0^{0} / 90^{0}\right]_{\mathrm{n}}$ are carried out. The dimensions of the stiffeners are $b_{x}=b_{y}=h$ and $h_{y}=h_{y}=(0.5 \div 5) h$.

This figure shows the natural fundamental frequencies of the stiffened shell panels with lamination scheme $\left[0^{0} / 90^{\circ}\right]_{3}$ are always higher than those with lamination scheme $\left[0^{0} / 90^{\circ}\right]_{1}$ and $\left[0^{\circ} / 90^{\circ}\right]_{2}$. 
It can be observed that the increase of the height of the stiffeners is not always the good way to reinforce well for the shell panels in Figs. 3-5. This can be shown clearly for the spherical shell panels.
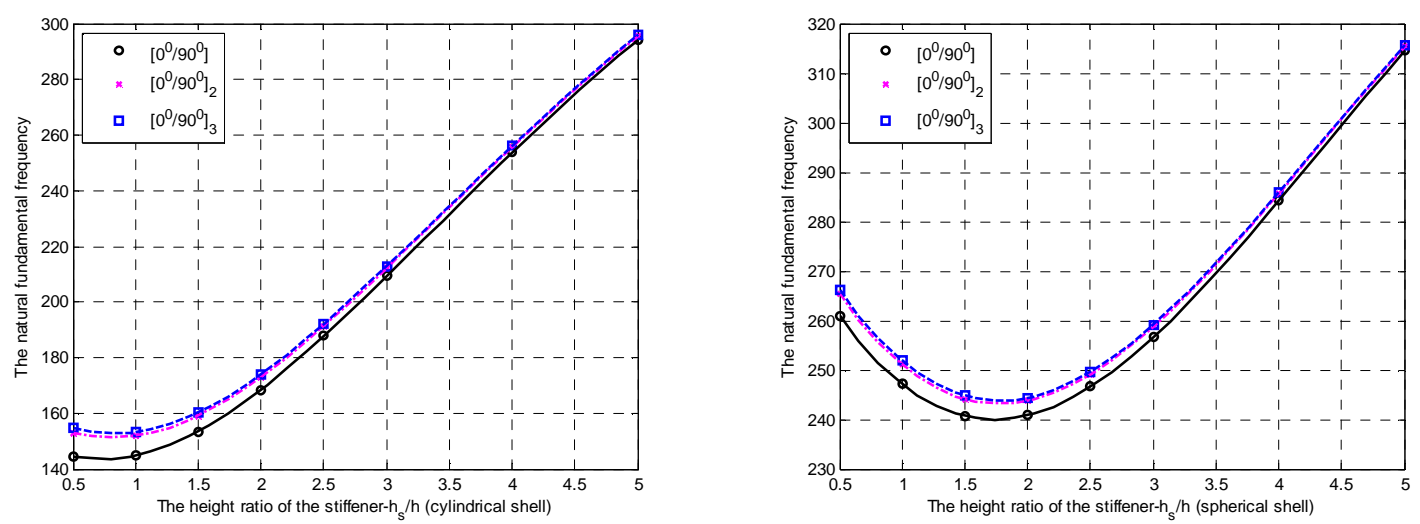

Figure 5. The effects of the lamination scheme of cross-ply laminated composite on the natural fundamental frequencies of the spherical shell and cylindrical shell panels with stiffeners.

\section{CONCLUSIONS}

In this work, the analytical solution for the free vibration of the cross-ply laminated composite doubly curved shallow shell panels with the simply supported boundary condition are presented. From the previous investigations, it can be noted that:

- With the dimensions of stiffeners used are $b_{x(y)}=h_{x(y)}=h$, the natural fundamental frequencies of the shell decrease when the number of the stiffeners increases. This phenomenon is due to the increase of the mass is faster than the increase of the stiffness of the shell panel. Besides, the rings reinforce for the shell panels are better than the others (more effective).

- For the cylindrical shell panels, when the height of stiffener is larger than twice the width of the stiffener $\left(b_{x}=b_{y}=h\right)$, the natural fundamental frequencies of the shell panel with orthogonal stiffeners are larger than those of with rings and stringers (more strength). However, for the spherical shell panels, when the height of the stiffener is larger than four times the width of the stiffener, the natural fundamental frequencies of the shell panel with orthogonal stiffeners are larger than those of the others (more strength).

- The natural fundamental frequency of the stiffened shell panels with lamination scheme $\left[0^{\circ} / 90^{\circ}\right]_{3}$ is always higher than those with lamination scheme $\left[0^{\circ} / 90^{\circ}\right]_{1}$ and $\left[0^{\circ} / 90^{\circ}\right]_{2}$.

- The increase of the height of stiffeners is not always the good way to reinforce well for the shell panels.

\section{REFERENCES}

1. Rinehart S. and Wang J. - Vibration of simply supported cylindrical shells with longitudinal stiffeners, Journal of Sound and Vibration 24 (2) (1972) 151-163.

2. Mustafa B. and Ali R. - An energy method for free vibration analysis of stiffened circular cylindrical shells, Computers \& structures 32 (2) (1989) 355-363. 
3. Mustafa B. and R. Ali - Prediction of natural frequency of vibration of stiffened cylindrical shells and orthogonally stiffened curved panels, Journal of Sound and Vibration 113 (2) (1987) 317-327.

4. Sinha G. and Mukhopadhyay M. - Finite element free vibration analysis of stiffened shells. Journal of sound and vibration 171 (4) 1994) 529-548.

5. Nayak A. and Bandyopadhyay J. - On the free vibration of stiffened shallow shells, Journal of Sound and Vibration 255 (2) (2002) 357-382.

6. Bich D. H., Van Dung D., and Nam V. H. - Nonlinear dynamical analysis of eccentrically stiffened functionally graded cylindrical panels, Composite Structures 94 (8) (2012) 2465-2473.

7. Bich D. H., Van Dung D., and Nam V. H. - Nonlinear dynamic analysis of eccentrically stiffened imperfect functionally graded doubly curved thin shallow shells, Composite Structures 96 (2013) 384-395.

8. Duc N. D. - Nonlinear dynamic response of imperfect eccentrically stiffened FGM double curved shallow shells on elastic foundation. Composite Structures 99 (2013) 88-96.

9. Duc N. D. and Quan T. Q. - Nonlinear postbuckling of imperfect eccentrically stiffened PFGM double curved thin shallow shells on elastic foundations in thermal environments. Composite Structures 106 (2013) 590-600.

10. Quan T. Q. and Dinh Duc N. - Nonlinear vibration and dynamic response of shear deformable imperfect functionally graded double-curved shallow shells resting on elastic foundations in thermal environments, Journal of Thermal Stresses 39 (4) (2016) 437-459.

11. Najafizadeh M., Hasani A., and Khazaeinejad P. - Mechanical stability of functionally graded stiffened cylindrical shells, Applied Mathematical Modelling 33 (2) (2009) 1151-1157.

12. Wattanasakulpong N. and Chaikittiratana A. - An analytical investigation on free vibration of FGM doubly curved shallow shells with stiffeners under thermal environment, Aerospace Science and Technology 40 (2015) 181-190.

13. Reddy J. N. - Exact solutions of moderately thick laminated shells, Journal of Engineering Mechanics 110 (5) (1984) 794-809.

14. Goswami S. and Mukhopadhyay M. - Finite element free vibration analysis of laminated composite stiffened shell, Journal of Composite Materials 29 (18) (1995) 2388-2422.

15. Prusty B. G. - Free vibration and buckling response of hat-stiffened composite panels under general loading, International Journal of Mechanical Sciences 50 (8) 2008) 1326-1333.

16. Nayak A. and Bandyopadhyay J. - Free vibration analysis of laminated stiffened shells, Journal of engineering mechanics 131 (1) (2005) 100-105.

17. Li D., Qing G., and Liu Y. - A layerwise/solid-element method for the composite stiffened laminated cylindrical shell structures, Composite Structures 98 (2013) 215-227.

18. Rikards R., Chate A., and Ozolinsh O. - Analysis for buckling and vibrations of composite stiffened shells and plates, Composite Structures 51 (4) (2001) 361-370.

19. Bert C. W., Kim C. D., and Birman V. - Vibration of composite-material cylindrical shells with ring and/or stringer stiffeners, Composite Structures 25 (1-4) (1993) 477-484.

20. Reddy J. N. - Mechanics of laminated composite plates and shells: theory and analysis, 2004: CRC press. 856. 